\title{
Quatrième partie - L'évolution des réseaux de chemins de fer secondaires / Présentation
}

\section{Maurice Wolkowitsch}

\section{OpenEdition}

\section{Journals}

Édition électronique

URL : https://journals.openedition.org/rhcf/1325

DOI : 10.4000/rhcf.1325

\section{Éditeur}

Rails \& histoire

\section{Édition imprimée}

Date de publication : 10 février 2004

Pagination : 281

ISBN : 0996-9403

ISSN : 0996-9403

\section{Référence électronique}

Maurice Wolkowitsch, «Quatrième partie - L'évolution des réseaux de chemins de fer secondaires / Présentation », Revue d'histoire des chemins de fer [En ligne], 30 | 2004, mis en ligne le 20 août 2012, consulté le 22 avril 2022. URL : http://journals.openedition.org/rhcf/1325 ; DOI : https://doi.org/ $10.4000 /$ rhcf. 1325

Ce document a été généré automatiquement le 22 avril 2022.

Tous droits réservés 


\title{
Quatrième partie - L'évolution des réseaux de chemins de fer secondaires / Présentation
}

\author{
Maurice Wolkowitsch
}

1 L'évolution des réseaux se produit au sein de deux milieux en voie de transformation dans des directions divergentes. Les villes s'étendent en surface et leur population croît ; ces mouvements sont indéniables, même s'ils sont plus lents que dans d'autres pays industrialisés. Une politique des transports urbains s'impose aux autorités qui ne peuvent sacrifier un service public de transport de plus en plus indispensable. Le milieu rural est atone, il se dépeuple, mal remis des saignées de la Grande Guerre, il demeure dans bien des régions dans son archaïsme agraire. Le maintien des services n'a pas le même caractère impératif qu'en ville.

2 La situation des réseaux de CFIL et de TVM et celle des réseaux de TV et de TVB doit être distinguée.

3 L'évolution porte sur trois données qu'on ne saurait confondre : le sort des entreprises privées ou publiques bénéficiaires d'une concession, l'évolution du nombre de kilomètres exploités par une entreprise ou dans un territoire définis, le nombre de ces kilomètres parcourus sur des voies ferrées ; si la part du réseau ferré en exploitation est l'objectif premier de cette étude cela n'exclut pas de mesurer le développement du réseau exploité par route. 
INDEX

Mots-clés : aménagement du territoire, chemin de fer, exploitation ferroviaire, France, infrastructure ferroviaire, politique des transports/France, chemin de fer secondaire

\section{AUTEUR}

MAURICE WOLKOWITSCH

Professeur émérite à l'université de la Méditerranée 